\title{
The Influence of Synthetic Pyrethroids on Memory Processes, Movement Activity and Co-Ordination in Mice
}

\author{
Barbara Nieradko-Iwanicka \\ Medical University of Lublin, Chair and Department of Hygiene
}

Poland

\section{Introduction}

In plants of Chrysanthemum species (Tancetum cinerariefolium, or Chrysanthemum cinerariefolium, or Pyrethrum cinerariefolium) there are natural compounds called pyrethrins of insecticidal properties. Since the beginning of the XIXth century the flowers of Chrysanthemum were used to fight nets and lice. In 1828 massive production of Chrysanthemum began in order to make an insecticidal formulas. Before World War II the main centers of Chrysanthemum production were Dalmatia and Japan. After World War II production of Chrysanthemum was launched in Africa (Kenia, Tanzania, Rwanda). Until 1920s kerosene extract of Chrysanthemum flowers was commonly used to fight nets, lice and mosquitoes. Initially, it was believed to be absolutely safe for users and it was recommended to take $10-20 \mathrm{mg}$ of the formula orally in adults or 5-10 $\mathrm{mg}$ in children to get rid of intestinal parasites. Adverse events of such use, especially skin reactions to pyrethrins were described afterwards (Casida J.E. 1980).

The chemical structure of pyrethrins was discovered by Herman Staudinger and Leopold Ruzicka between 1910 and 1916 (Casida J.E. 1980). Thre six natural pyrethrins (pyrethrin I, pyrethrin II, cinerin I, cinerin II, jasmolin I and jasmolin II) are esters of two cyclopropanecarboxylic acids and three cyclopentenolone alcohols (piretrol, jasmolol or cynerol) (Różański, 1998).

The main drawback pf pyrethrins was their instability in light and air and lack of residual activity after single use, which made them unsuitable for use in agriculture for crop protection from pest insects (Soderlund 2002).

In 1949 allethrin -the first syntheic pyrethroid was produced (Bradberry et al., 2005). It was followed by resmethrin, tetramethrin, bifenthrin and tefluthrin. Permethrin was the first pyrethroid of enough photostability to be used in agriculture. In current use there are mainly permethrin, deltamethrin, cypermethrin cyfluthrin, cyhalothrin and fenpropathrin (Soderlund 2002). These compounds exhibit strong insecticidal activity and photostability.

Since the 1970s pyrethroids have been used in public health to prevent vector born diseases like malaria (Soderlund 2002). Malaria affects people in over 110 tropical and subtropical countries. About one million people die every year because of it. Clinical symptoms of malaria develop in almost 500 million people per year (Kajfasz 2011). It is estimated, that about 15 thousand Europeans import malaria from tropical countries 
every year (Knap \& Myjak 2009). Current climate change is expected to have a substantial effect on the burden of mosquitoes such as anopheles species, which transmit malaria and other mosquito-borne diseases like West Nile virus infection (Shuman 2010). With global temperatures increase by 2 to $3^{\circ} \mathrm{C}$, the population at risk for malaria is expected to increase by $3-5 \%$, i. e. millions of additional people would probably become infected with malaria each year (Shuman 2010). Therefore people use bednets soaked with pyrethroids or spray them indoors or outdoors to protect themselves from insect vectors carrying diseases. This means prolonged (subchronic or chronic) exposure of humans (considered to be the non-target organisms) to pyrethroid insecticides. Side effects of such uses are not fully understood and need further studies.

Pyrethroids are also commonly used in veterinary medicine, for agricultural and horticultural purposes. It was estimated, that pyrethroid use has increased to reach about $23 \%$ of the world insecticide market (Soderlund 2002). Even though organophosphates still are in wide use as insecticides (Casida \& Quistad, 1998), there is evidence that they contaminate groundwaters (Badach et al., 2007; Drożdżyński 2008) , are able to accumulate in fatty tissue of living organisms (Molina et al., 2005) and can irreversibly damage the hippocampal structure in the central nervous system of mammals (Mitra et al., 2008). As hippocampus plays a key role in memory processes, it might impair memory in humans exposed to organophosphates. Therefore there is a growing interest in pyrethoids and so is their use. However, the knowledge of pyrethroids' effects on memory processes and movement activity in non-target organisms is incomplete.

Pyrethoids act as acute neurotoxins (Soderlund 2002). They alter functioning of nerves in target animals by modifying the kinetic characteristics of voltage sensitive sodium channels (Soderlund \& Bloomquist, 1989; Bloomquist 1993).

Before 1970s little was known about mammalian toxicity of pyrethroids. The first study documenting modest oral toxicity of pyrethrins and pyrethoids in rats was published in 1972 ( Verschoyle \& Barnes, 1972). Acute mammalian toxicity of pyrethroids and structuretoxicity relationships were elucidated after numerous experiments with intracerebral and intravenous administration of these neurotoxins to mice and rats (Verschoylea \& Aldridge, 1980; Lawrence \& Casida,1982).

The milestone in pyrethroid improvement was the discovery of the fact that the presence of an a-cyano substituent in S configuration in the 3- phenoxybenzyl alcohol moiety greatly enhanced neurotoxicity in mammals as well as in insects (Elliot et al. 1974; Soderlund 2002). There were found pyrethroid structure-toxicity relationships in mammals, which were congruent with those found in insects (Soderlund 2002). The studies from 1970s provided the first descriptions of signs of pyrethroid intoxication in mammals after oral and intravenous dosing (Verschoyle \& Barnes 1972). The authors described hypersensitivity and aggression followed by tremor, coma, an eventually death after exposure of the experiment rats to bioallethrin and resmethrin orally or intravenously (Verschoyle \& Barnes 1972). The first pyrethroid containing the a-cyano-3-phenoxybenzyl moiety was deltamethrin (Elliot et al. 1974). Oral or intravenous exposure of rats to deltamethrin produced salivation, jerking leg movements and choreoatetosis (Elliot et al. 1974). In 1980 pyrethroids were divided into two groups: those producing T-syndrome (tremor) and those producing CS-syndrome (choreoatetosis and salivation) (Verschoyle \& Aldridge 1980). It was found then, that majority of pyrethroids containing the a-cyano-3-phenoxybenzyl moiety produced the CSsyndrome, and those without the a-cyano-3-phenoxybenzyl moiety produced the Tsyndrome. 
In 1982 a new nomenclature for pyrethroids (Type I/II) was proposed basing on the syndromes of intoxication in mammals (Lawrence \& Casida 1982). This nomenclature is used parallel to the T/CS nomenclature in many publications. Type I pyrethroids are considered to produce the T-syndrome, and Type II the CS-syndrome. However, there were some pyrethroids that were tested neither in the study about Type I/II nor T/CS pyrethroids, for example bifentrin and cyhalothrin. Also, in the classifying studies pyrethroids were administered orally, intravenously or intracerebrally (Verschoyle \& Aldridge 1980; Lawrence \& Casida 1982). However the most likely routes of pyrethroid intake by humans is orally, by inhalation and transdermally. The transdermal absorption of pyrethroids is most likely in greenhouse workers and farmers. It is also possible in holidaymakers or campers who use ' mosquito repellent' containing pyrethroids all evening or day and night. Pyrethroid containing formulas available on the market usually have enclosed leaflet warning the users about skin reactions to the chemicals and suggest symptomatic treatment if they develop. There is little or no information about their main mechanism of toxic action- about neurotoxicity.

The aim of this chapter is to analyze the influence of synthetic pyrethroids injected intraperitioneally to female Albino Swiss mice at the doe of $0.1 \mathrm{LD}_{50}$ on memory processes, movement activity and co-ordination. The pyrethroids chosen were lambda-cyhalothrin, deltamethrin, cypermethrin, fenpropathrin and bifenthrin.

\section{Material and methods}

\subsection{Animals}

Non-gravid female albino Swiss mice weighing 18-24g approximately 6 weeks of age purchased from a licensed dealer (T. Górzkowski, Warsaw, Poland) were used in the study. All animals were given a 7-day acclimation period and maintained on a $12 \mathrm{hr}$ light/dark cycle. Food and tap water were provided ad libitum. Temperature was maintained at $21 \pm$ $2^{\circ} \mathrm{C}$.

\subsubsection{Groups of animals}

There were two groups of animals in each experiment: I injected with $0.9 \% \mathrm{NaCl}$ i.p. and II injected with a pyrethroid (lambda-cyhalothrin, deltamethrin, cypermethrin, fenpropathrin or bifenthrin) at the dose of $0.1 \mathrm{LD}_{50}$ i.p. The injections were made $15 \mathrm{~min}$. before beginning each experiment. In passive avoidance task the injections were given once only -15 min. before training.

\subsubsection{Opinion of the local ethics committee}

The Local Ethics Committee for Animal Experiments in Lublin approved the experiment (Opinion No. 30/2000, dated 24.11.2000).

\subsection{Materials}

Bifenthrin (powder 99,6 $60,2 \%$ ) in glasses $0,1 \mathrm{~g}$ each was purchased from the manufacturer Institute of Industrial Organic Chemistry, Annopol 6, 03-236 Warsaw, Poland.

Cypermethhrin (powder 99,7\%) in glasses 0,25g each was purchased from the manufacturer - Institute of Industrial Organic Chemistry, Annopol 6, 03-236 Warsaw, Poland.

Deltamethrin (powder 99,7\%) in glasses 0,25g each was purchased from the manufacturer Institute of Industrial Organic Chemistry, Annopol 6, 03-236 Warsaw, Poland. 
Fenpropathrin (powder 99,4 $\pm 0,3 \%$ ) in glasses $0,25 \mathrm{~g}$ each was purchased from the manufacturer - Institute of Industrial Organic Chemistry, Annopol 6, 03-236 Warsaw, Poland.

Lambda-cyhalothrin (Karate 025EC containing 25g of lambda-cyhalothrin per 1 litre) was purchased from the manufacturer Syngentia Limited, United Kingdom.

In order to suspend the pyrethroids in bidistilled water Tween 60 (poloxyethylene sorbitan monostearate $100 \%$ in glasses $250 \mathrm{~g}$ each was purchased from the manufacturer Laboratorium Reagenzien, Germany) was used. Analytic weighing scale manufactured at Radwag, Poland was used.

Water was bidistilled at the Hygiene Department of Medical University of Lublin.

$0.9 \% \mathrm{NaCl}$ for control animals was prepared at the Hygiene Department of Medical University of Lublin.

\subsection{Dosing}

$\mathrm{LD}_{50}$ of each pyrethroid was calculated with Lichtfield and Wilcoxon's method (Lichtfield \& Wilcoxon 1949).

$\mathrm{LD}_{50}$ for bifenthrin in mice was calculated to be $16.1 \mathrm{mg} / \mathrm{kg}$ of bw [13.1-19.7].

$\mathrm{LD}_{50}$ for cypermethrin in mice was calculated to be $169.9 \mathrm{mg} / \mathrm{kg}$ of bw [151.9-190.1].

$\mathrm{LD}_{50}$ for deltamethrin in mice was calculated to be $83 \mathrm{mg} / \mathrm{kg}$ of bw [79.2-87].

LD50 for fenpropathrin in mice was calculated to be $23.8 \mathrm{mg} / \mathrm{kg}$ of bw [21.2-26.7].

LD50 for lambda-cyhalothrin in mice was calculated to be $6.9 \mathrm{mg} / \mathrm{kg}$ of bw [5.5-8.5].

At the beginning of each experiment 0.1 of $\mathrm{LD}_{50}$ of the tested pyrethroid was injected i.p. to each animal from group II. Controls were mice from group I, that received respective volume of $0.9 \% \mathrm{NaCl}$ i.p.

\subsection{Behavioral tests}

\subsubsection{Passive avoidance}

A step-through passive avoidance (PA) task was used in the study. The task relies on the innate preference of rodents for dark, enclosed spaces and it is regarded as a measure of long-term memory retention. Avoidance training consisted of a single trial in which each animal was placed in an illuminated box $(15 \times 12 \times 15 \mathrm{~cm})$ adjacent to a darkened one (the same size) with an electric grid floor. A $4 \times 5 \mathrm{~cm}$ doorway was located at floor level in the center of the wall separating the boxes. Thirty second after placing the animal in the centre of the illuminated box a passage joining the two boxes was opened. After entering the dark box the animal was punished with an electric foot shock ( $2 \mathrm{~mA}$ for $2 \mathrm{~s})$. Twenty four hours after the training trial memory retention test was conducted in which the same animals were placed in the illuminated box and the latency to enter the darkened box was recorded. The test ended when the mouse entered the darkened box or when 180s has elapsed. Mice that did not enter in the time allotted received latency 180s. Administration of the tested pesticide before training may impair or improve learning by affecting memory acquisition and/or recalling.

\subsubsection{Y-maze task}

Spontaneous alternation was assessed in a Y-maze, which is used as a measure of working spatial memory. The total number of arm entries in Y-maze can be also considered a measure of exploratory locomotor activity. The Y- maze consists of three $10 \times 10 \times 10 \mathrm{~cm}$ compartments without floor joined together with $4-\mathrm{cm}$ long corridors at $120^{\circ}$ in such a way 
that each corridor opens to one compartment only. The maze is placed on a clean sheet of paper on a table-top. In order to prevent odor cues, the maze was cleaned between the trials of different mice and a clean sheet of paper was used for each animal. Mice naturally tend to explore the maze by systematically entering each arm. The ability to alternate requires that the animals knew which arm they have already visited. In the task, each mice was placed at the end of one arm and was allowed to move through the maze for $8 \mathrm{~min}$. The percentage of alternation, defined as consecutive entries into all three arms without repetitions in overlapping triplet sets, to all possible alternations $\times 100 \%$ was counted. For example, if the arms were marked as $X, Y$ and $Z$ and the animal entered the arms in a following order XYZXZYZXYXYZXZ, the actual alternation would be 7, the total number of arm entries would be 14 and the percent alternation would be $58.33 \%$.

\subsubsection{Movement activity}

Horizontal spontaneous locomotor activity was assessed with an automated device consisting of a circular box (32 cm in diameter) with two photocells mounted horizontally 2 $\mathrm{cm}$ above the floor at the angle of $90^{\circ}$. The photo-beam was activated when the mouse interrupted the beam. In the task the animals were not habituated for the apparatus, therefore they were placed individually in the actometers for 1 hour (two subsequent 30-min periods: $0 .-30$. $\mathrm{min}, 31 .-60$. min). The number of impulses was recorded after 30 and $60 \mathrm{~min}$. The first period was considered as a rate of exploratory locomotor activity. The second period was considered as a rate of spontaneous locomotor activity.

\subsubsection{Movement co-ordination}

Movement co-ordination was examined on a rod rotating at the rate of 10 cycles per min. The animals were placed on the rod $(1 \mathrm{~cm}$ diameter $) 50 \mathrm{~cm}$ above the ground for $120 \mathrm{sec}$. The trial ended when the mouse fell off the rod or $120 \mathrm{~s}$ had elapsed, whichever occurred first.

\subsection{Statistical analyses}

A Kruskall-Wallis non- parametric ANOVA test was used to analyze the data from passive avoidance task. PA results were expressed as median values with the $25^{\text {th }}$ and $75^{\text {th }}$ percentiles. The results of spontaneous alternation in Y-maze task, movement co-ordination and spontaneous motor activity were shown as means \pm SEM, and evaluated by one-way analysis of variance ANOVA followed by Student- Newman-Keuls test. The $p$ value $<0.05$ was considered statistically significant.

\section{Results}

\subsubsection{Effect of bifenthrin on memory retention in passive avoidance task}

No statistically significant difference was observed in memory retention between group I and II. Median values of latency (with the $25^{\text {th }}$ and $75^{\text {th }}$ percentiles) were: $180 \mathrm{sec}$. $(180,180)$ in group I (control) and $180 \mathrm{sec}$. $(180,180)$ in group II $\left(0.1 \mathrm{LD}_{50}\right.$ of bifenthrin i.p.). Post test were not calculated; $\mathrm{p}>0.05$. There were 10 mice in each group.

\subsubsection{Influence of bifenthrin on working spatial memory in $\mathrm{Y}$ - maze task}

There was a statistically significant difference between the examined groups in working spatial memory. Results obtained were (\% of logical alternation behaviour expressed as 
mean \pm SEM) : group I (control) $62.2 \pm 1.601$; group II (0.1 LD50 of bifenthrin i.p.) $52.59 \pm$ 2.932; $\mathrm{p}=0.0116$ considered significant. There were 10 mice in each group (Fig.1.).

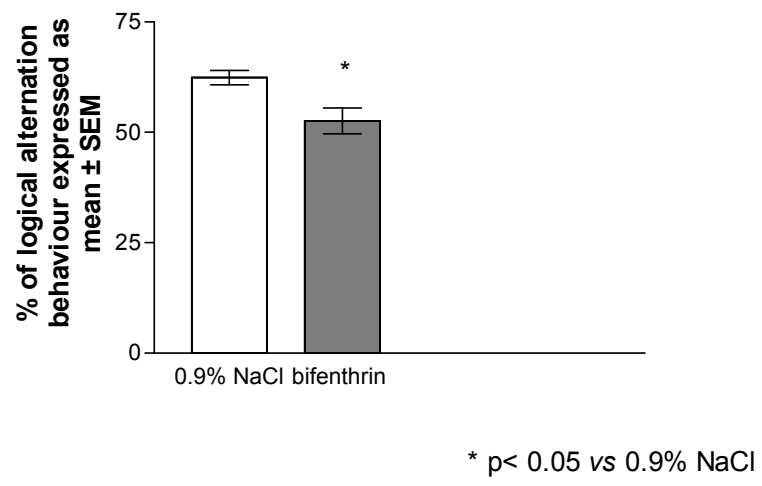

Fig. 1.The influence of bifenthrin $\left(0.1 \mathrm{LD}_{50}\right.$ i.p.) on working spatial memory in Y-maze task. Columns represent the means \pm SEM. Number of mice in each group was 10 . ${ }^{*} p<0.05 v s$ $0.9 \% \mathrm{NaCl}$ (ANOVA).

\subsubsection{Influence of bifenthrin on movement activity in the actometer}

The results of movement activity assessed within the 0-30 min. of observation were significantly different in the groups. Mean values \pm SEM were: group I (control) $521.4 \pm$ 33.903; group II ( $0.1 \mathrm{LD}_{50}$ of bifenthrin i.p.) $664.9 \pm 37.721 ; \mathrm{p}=0.0116$ considered significant. There were 10 mice in each group.

The movement activity assessed within the 31-60 min. of observation did not significantly differ. Mean values \pm SEM were: group I (control) $342.9 \pm 39.672$; group II $\left(0.1 \mathrm{LD}_{50}\right.$ of bifenthrin i.p.) $346.6 \pm 33.532$.p $>0.05$ considered not significant. There were 10 mice in each group (Fig.2.).

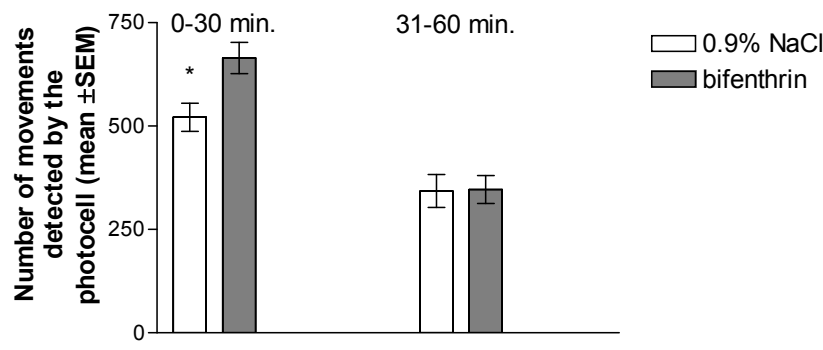

${ }^{*} p<0.05$ vs bifenthrin

Fig. 2. The influence of bifenthrin $\left(0.1 \mathrm{LD}_{50}\right.$ i.p.) on movement activity in the actometer. Columns represent the means \pm SEM. Number of mice in each group was 10 . ${ }^{*} \mathrm{p}<0.05$ vs bifenthrin (ANOVA). 


\subsubsection{Influence of bifenthrin on movement coordination}

There was observed a statistically significant difference between the examined groups in movement coordination. The mean times of fully coordinated gait on the rotating rod in sec. ( \pm SEM) were: group I (control) $119 \pm 1.0$; group II (0.1 LD Lo $_{50}$ of bifenthrin i.p.) 78.2 \pm 17.285 . $\mathrm{p}=0.03$ considered significant. There were 10 mice in each group (Fig.3).

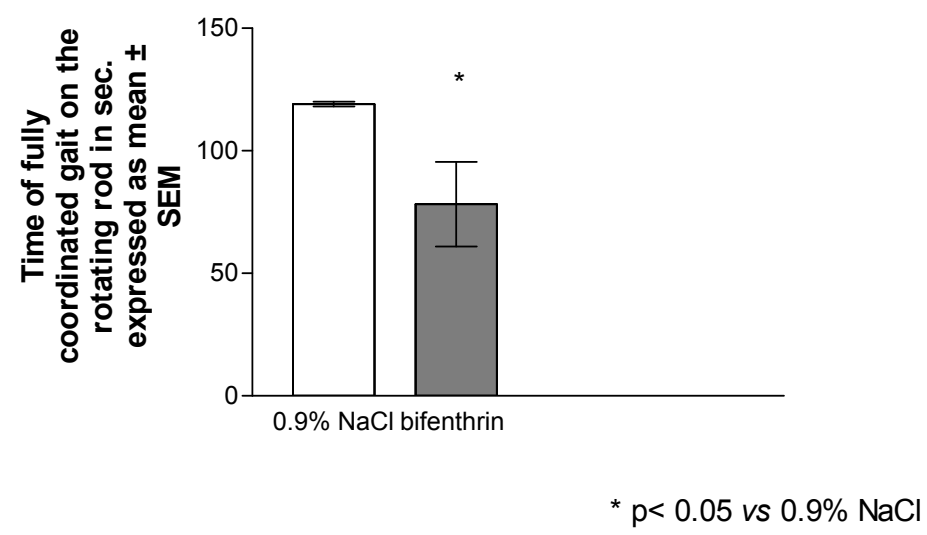

Fig. 3. The influence of bifenthrin ( $0.1 \mathrm{LD}_{50}$ i.p.) on movement coordination. Columns represent the means \pm SEM. Number of mice in each group was $10 .{ }^{*} p<0.05$ vs $0.9 \% \mathrm{NaCl}$ (ANOVA).

\subsubsection{Effect of cypermethrin on memory retention in passive avoidance task}

No statistically significant difference was observed in memory retention between group I and II. Median values of latency (with the $25^{\text {th }}$ and $75^{\text {th }}$ percentiles) were: $180 \mathrm{sec} .(180,180)$ in group I (control) and $172.5 \mathrm{sec} .(40,180)$ in group II $\left(0.1 \mathrm{LD}_{50}\right.$ of cypermethrin i.p.). Post test were not calculated; $\mathrm{p}>0.05$. There were 10 mice in each group.

\subsubsection{Influence of cypermethrin on working spatial memory in Y-maze task}

There was no statistically significant difference between the examined groups in working spatial memory. Results obtained were (\% of logical alternation behaviour expressed as mean \pm SEM): group I (control) $64.47 \pm 2.361$; group II ( $0.1 \mathrm{LD}_{50}$ of cypermethrin i.p.) $59.41 \pm$ $2.853 ; \mathrm{p}>0.5$ considered not significant. There were 10 mice in each group.

\subsubsection{Influence of cypermethrin on movement activity in the actometer}

The movement activity assessed within the 0-30 min. of observation were not significantly different in the groups. Mean values \pm SEM were: group I (control) $552.44 \pm 66.165$; group II (0.1 LD 50 of cypermethrin i.p.) $368.125 \pm 87.653$; $\mathrm{p}>0.05$ considered not significant. There were 10 mice in each group.

The movement activity assessed within the 31-60 min. of observation did not significantly differ. Mean values \pm SEM were: group I (control) $394.66 \pm 40.48$; group II $\left(0.1 \mathrm{LD}_{50}\right.$ of cypermethrin i.p.) $260 \pm 107.11 ; \mathrm{p}>0.05$ considered not significant. There were 10 mice in each group. 


\subsubsection{Influence of cypermethrin on movement coordination}

There was observed no statistically significant difference between the examined groups in movement coordination. The mean times of fully coordinated gait on the rotating rod in sec. ( \pm SEM) were: group I (control) $120 \pm 0.0$; group II ( $0.1 \mathrm{LD}_{50}$ of cypermethrin i.p.) $120 \pm 0.0$. There were 10 mice in each group.

\subsubsection{Effect of deltamethrin on memory retention in passive avoidance task}

No statistically significant difference was observed in memory retention between group I and II. Median values of latency (with the $25^{\text {th }}$ and $75^{\text {th }}$ percentiles) were: $180 \mathrm{sec} .(180,180)$ in group I (control) and $180 \mathrm{sec} .(65,180)$ in group II $\left(0.1 \mathrm{LD}_{50}\right.$ of deltamethrin i.p.). Post test were not calculated; $p>0.05$. There were 10 mice in each group.

\subsubsection{Influence of deltamethrin on working spatial memory in Y-maze task}

There was no statistically significant difference between the examined groups in working spatial memory. Results obtained were (\% of logical alternation behaviour expressed as mean \pm SEM): group I (control) $61.84 \pm 1.492$; group II ( $0.1 \mathrm{LD}_{50}$ of deltamethrin i.p.) $56.22 \pm$ $3.274 ; \mathrm{p}>0.5$ considered not significant. There were 10 mice in each group.

\subsubsection{Influence of deltamethrin on movement activity in the actometer}

The movement activity results analyzed within the 0-30 $\mathrm{min}$. of observation were not significantly different in the groups. Mean values \pm SEM were: group I (control) $728.66 \pm$ 288.62; group II (0.1 LD 50 of deltamethrin i.p.) $417 \pm 50.964 ; p>0.05$ considered not significant.

The movement activity assessed within the 31-60 min. of observation did not significantly differ between the examined groups. Mean values \pm SEM were: group I (control) $608.66 \pm$ 371.16; group II (0.1 LD50 of deltamethrin i.p.) $215.66 \pm 41.571 ; p>0.05$ considered not significant.

\subsubsection{Influence of deltamethrin on movement coordination}

There was observed no statistically significant difference between the examined groups in movement coordination. The mean times of fully coordinated gait on the rotating rod in sec. ( \pm SEM) were: group I (control) $112.2 \pm 7.8$; group II (0.1 LD 50 of deltamethrin i.p.) $82 \pm$ $15.721 ; \mathrm{p}>0.05$ considered not significant. There were 10 mice in each group.

\subsubsection{Effect of fenpropathrin on memory retention in passive avoidance task}

No statistically significant difference was observed in memory retention between group I and II. Median values of latency (with the $25^{\text {th }}$ and $75^{\text {th }}$ percentiles) were: $180 \mathrm{sec} .(180,180)$ in group I (control) and 30 sec. 135, 180) in group II $\left(0.1 \mathrm{LD}_{50}\right.$ of fenpropathrin i.p.). Post test were not calculated. There were 10 mice in each group.

\subsubsection{Influence of fenpropathrin on working spatial memory in Y- maze task}

There was no statistically significant difference between the examined groups in working spatial memory. Results obtained were (\% of logical alternation behaviour expressed as mean \pm SEM): group I (control) $62.38 \pm 1.709$; group II ( $0.1 \mathrm{LD}_{50}$ of fenpropathrin i.p.) $61.88 \pm$ $3.379 ; p>0.5$ considered not significant. There were 10 mice in each group. 


\subsubsection{Influence of fenpropathrin on movement activity in the actometer}

The results of movement activity measurement analyzed within the 0-30 min. of observation were not significantly different in the examined groups. Mean values \pm SEM were: group I (control) $524.44 \pm 64.61$; group II ( $0.1 \mathrm{LD}_{50}$ of fenpropathrin i.p.) $456 \pm 45.128$; p > 0.05 considered not significant.

The movement activity assessed within the 31-60 min. of observation did not significantly differ between the examined groups. Mean values \pm SEM were: group I (control) $360 \pm$ 51.465 ; group II (0.1 LD 50 of fenpropathrin i.p.) $316.77 \pm 34.44 ; \mathrm{p}>0.05$ considered not significant. There were 10 mice in each group.

\subsubsection{Influence of fenpropathrin on movement coordination}

There was observed no statistically significant difference between the examined groups in movement coordination. The mean times of fully coordinated gait on the rotating rod in sec. ( \pm SEM) were: group I (control) $112.3 \pm 7.7$; group II (0.1 LD 50 of fenpropathrin i.p.) $105.8 \pm$ $9.881 ; p>0.05$ considered not significant. There were 10 mice in each group.

\subsubsection{Effect of lambda-cyhalothrin on memory retention in passive avoidance task}

No statistically significant difference was observed in memory retention between group I and II. Median values of latency (with the $25^{\text {th }}$ and $75^{\text {th }}$ percentiles) were: $180 \mathrm{sec} .(180,180)$ in group I (control) and $180 \mathrm{sec} .(15,180)$ in group II $\left(0.1 \mathrm{LD}_{50}\right.$ of lambda-cyhalothrin i.p.). p $>0.05$ considered not significant. Post test were not calculated. There were 10 mice in each group.

\subsubsection{Influence of lambda-cyhalothrin on working spatial memory in Y- maze task}

There was no statistically significant difference between the examined groups in working spatial memory. Results obtained were (\% of logical alternation behaviour expressed as mean \pm SEM): group I (control) $62.57 \pm 2.875$; group II (0.1 LD 50 of lambdacyhalothrin i.p.) $61.83 \pm 1.865 ; \mathrm{p}>0.5$ considered not significant. There were 10 mice in each group.

\subsubsection{Influence of lambda-cyhalothrin on movement activity in the actometer}

The movement activity results analyzed within the 0-30 $\mathrm{min}$. of observation were not significantly different in the examined groups. Mean values \pm SEM were: group I (control) $546.8 \pm 28.171$; group II $\left(0.1 \mathrm{LD}_{50}\right.$ of lambda-cyhalothrin i.p.) $491.9 \pm 28.917 ; \mathrm{p}>0.05$ considered not significant.

The movement activity assessed within the 31-60 min. of observation did not significantly differ between the examined groups. Mean values \pm SEM were: group I (control) $357.8 \pm$ 31.48 ; group II ( $0.1 \mathrm{LD}_{50}$ of lambda-cyhalothrin i.p.) $291.4 \pm 22.935 ; \mathrm{p}>0.05$ considered not significant. There were 10 mice in each group.

\subsubsection{Influence of lambda-cyhalothrin on movement coordination}

There was observed no statistically significant difference between the examined groups in movement coordination. The mean times of fully coordinated gait on the rotating rod in sec. ( \pm SEM) were: group I (control) $119 \pm 1.0$; group II ( $0.1 \mathrm{LD}_{50}$ of lambdacyhalothrin i.p.) $107.6 \pm 9.48 ; \mathrm{p}>0.05$ considered not significant. There were 10 mice in each group. 


\section{Discussion}

In this work bifenthrin administered i.p. at the dose of $0.1 \mathrm{LD}_{50}$ was the only pesticide tested, that produced significant changes in mice bahaviour. Bifenthrin administered once $15 \mathrm{~min}$. before testing in the Y-maze has significantly impaired the spatial working memory in comparison with the control group (Fig.1.). Bifenthrin was also found to impair movement coordination (Fig.3.). Bifenthrin has significantly increased movement activity within 0-30 min. of examination in the actometer (Fig.2.). In the previous acute neurotoxicity studies bifenthrin administered orally to male and female rats at the dose of $75 \mathrm{mg} / \mathrm{kg}$ bw was found to produce whole body tremors, twitching, staggered gait, uncoordinated movement, ataxia, splayed hindlimbs, abnormal posture, clonic convulsions and abdominogenital staining (Watt 1998). Bifenthrin is an non-cyano pyrethroid, which was not included in the original studies estabilishing the T/CS classification. At present bifenthrin is classified as Type I (producing T-syndrome) ( Breckendridge et al. 2009). All the above data show its toxicity and suggest possibe side effects of use in non-target organisms, like humans.

Cypermethrin administered i.p. at low dose in this work to female mice did dot significantly affect memory and movement. In previous studies cypermethrin was identified as producing the CS syndrome (Verschoyle \& Aldridge 1980; Lawrence \& Casida 1982). In experiments with male and female rats given 100 or $200 \mathrm{mg}$ of cypermethrin / $\mathrm{kg}$ bw in corn oil salivation, oral discharge, abdominogenital staining, ataxia, staggered gait, decreased locomotor activity and mortality were observed (Freeman 1993).

Deltamethrin did not affect movement non memory in this set of experiments. Deltamethrin is classified as producing the CS intoxication syndrome (Barnes \& Verschoyle 1974). The acute neurotoxicity studies of deltamethrin were conducted on male and female rats (Nemec 1998). Deltamethrin was administered orally in corn oil at the dose of $50 \mathrm{mg} / \mathrm{kg}$ bw. Deltamethrin administered this way produced salivation, a flattened posture, limb extension, clonic and tonic convulsions, tremor, biting the cage, eyelid ptosis, decreased reaction to removal and handling, lacrimation, decreased arousal, wave-like movements of the abdomen dragging hindlimbs, decreased response to stimuli, increased auditory startle response, reduced forelimb strength, decreased fore- and hindlimb extensor strength, hypothermia and mortality (Nemec 1998).

Lambda-cyhalothrin did not produce any statistically significant effect on memory processes nor movement activity in mice tested in this experiment. Cyhalothrin is a member of the a-cyano-3-phenoxybenzyl subfamily of pyrethroids (Soderlund 2002). However, it was not included in the T/CS classification as the effect of acute intoxication with lambdacyhalothrin were not specific to any of theses types. Lambda-cyhalothrin administered orally at the dose of $35 \mathrm{mg} / \mathrm{kg}$ bw in corn oil to rats caused decreased activity, ataxia, reduced stability, tiptoe gait, decreased landing foot splay and decreased tail flick response (Barmmer 1999).

There is data, that pyrethroids (cypermethrin, deltamethrin) administered orally in corn oil to rats produce dose-dependent decrease in motor activity (Crofton \& Reiter 1984, $1988 \mathrm{a}, \mathrm{b}$ ). There was evidence that i.p. administration of deltamethrin to rats caused a dose-dependent reduction in frequency of a prevuoisly learned behaviour (Bloom et al. 1983; Stein et al. 1987) which is congruent with data obtained in this work. Deltamethrin administered orally to rats for 15 days reduced learning and memory measured in a Y- maze task (Husain et al. 1996). Oral administration of cypermethrin to rats caused a similar reduction in learned bahaviour (Peele \& Crofton 1987). 
Fenpropathrin does not fit into the traditional classification of pyrethroids ( T/CS). In our former study ( Nieradko-Iwanicka \& Borzęcki 2010) fenpropathrin together with transient incomplete brain ischemia were found to reduce latency in the passive avoidance task compared to controls.

\section{Conclusion}

Pyrethroids, especially bifenthrin, should be used with caution as insecticidal formulas containing it may impair memory and movement in non target animals.

\section{References}

Badach H. et al. (2007) Pesticide content in drinking water samples collected from orchard areas in central Poland. Ann Agric Environ Med, 14, pp. 109-114.

Barmmer A. (1999) Lambda-cyhalothrin: acute neurotoxicity study in rats. Zeneca Agricultural Products Laboratory Study No. CTL/P/6151: AR 6699.

Barnes J.M., Verschoyle R.D. (1974). Toxicity of new pyrethroid insecticide. Nature 248, pp. 711.

Bloom A.S., Staatz C.G., Dieringer T. (1983) Pyrethroid Effects on operant responding and condiotioning ) Neurobehav Toxicol Teratol 5, pp. 321-324.

Bloomquist J.R. (1993) Neuroreceptor mechanisms in pyrethroid mode of action and resistance In: Reviews in Pesticide Toxicology Roe, M., KuhrR.J. (Eds.), , Toxicology Communications, Raleigh, NC, pp. 181-226.

Bradberry S.M., et al. (2005) Poisonong due to pyrethroids. Toxicol Rev, 24 (2)pp. 93-106.

Breckendridge C.B., Holden L., Struggerss N., Weiner M., Sheets L., Sargent D., Soderlund D.M., Choi J.-S., Symington S., Clark J.M., Burr S., Ray D. (2009) Evidence for separate mechanism of toxicity for the Type I and the Type II pyrethroid insecticides. Neurotocicology, 30, pp.17-31.

Casida J.E et al. (1980) Metabolic chemistry of pyrethroid insecticides. Pestic Sci, 11, pp. 257269.

Casida J.E., Quistad G.B. ( 1998) Golden age of insecticide research: past, present, or future? Annu Rev Entomol 43, pp.1-16.

Crofton K.M., Reiter L.W. (1984) Effects of two pyrethroid insecticides on motor activity and acoustic startle response in the rat. Toxicol Appl Phasrmacol 75, pp. 318-328.

Crofton K.M., Reiter L.W. (1988a) The effects of Type I and II pyrethroids on motor activity and acoustic startle response in the rat. Fund Appl Toxicol, 10, pp. 624-634.

Crofton K.M., Reiter L.W. (1988b) Pyrthroid insecticides and gamma-aminobutyric acid receptor complex. Mptor activity and acoustic startle response in the rat. $J$ Pharmacol Exp Ther 243, pp. 946-954.

Drożdzyński D. (2008) Studies on residues of pesticides used in rape plants protection in surface waters of intensively exploited arable lands in Wielkopolska Province of Poland. Ann Agric Environ Med, 15, pp. 231-235.

Elliot M., Farnham A.W., Janes N.F., Needham P.H., Pulman D.A., (1974) Synthetic insecticide with a new order of activity. Nature 248, pp.710-711.

Freeman C. (1993) Cypermethrin technical: acute neurotoxicity screen in rats. FMC Corporation study No. A92-3542. 
Husain R., Adhami V.M., Seth P.K. (1996) Behavioral, neurochemical, and neuromorphological effects of deltamethrin in adult rats. J Toxicol Environ Health 48 , pp. 515-526.

Kajfasz P. (2011) (Pol.) Profilaktyka chorób tropikalnych. Medycyna po Dyplomie 6 (18)3, pp. 34-41.

Knap J.P \& Myjak P. (2009) (Pol.) Malaria w Polsce i na świecie- wczoraj i dziś. a-medica Press Wydanie II (uzupełnione). Bielsko-Biała , pp.36.

Lawrence L.J., Casida J.E. ( 1982) Pyrethroid tocxicology: Mouse intracerebral structuretoxicity relationships. Pestic Biochem Physiol, 18, pp.9-14.

Lichtfield J.T., Wilcoxon F.A. ( 1949) Simplified method of evaluating dose-effect experiments. J Pharmacol Exp Ther, 96. pp.99-113.

Mitra N.K. et al.( 2008) Evaluation of neurotoxicity of repeated dermal application of chloprioryfos on hippocampus of adult mice. Ann Agric Environ Med, 15,pp. 211216.

Molina C. et al.( 2005) HCH and DDT residues in human fat in the population of Murcia (Spain). Ann Agric Environ Med, 12 , pp. 133-136.

Nemec M (1998) An acute neurotoxicity study of deltamethrin in rats AgroEvo USA Company Study No. 53014.

Nieradko-Iwanicka B., Borzęcki A. (2010) Infl;uence of fenpropathrin on memory and movement in mice after transient incomplete cerebral ischemia. J Toxicol Environ Health A 73, pp. 1166-1172.

Peele D.B., crofton K.M. (1987) Pyrethroid effects on schedule- controlled behavior: time and dosage relationships. Neurotoxicol Teratol 9, pp. 387-394.

Różański L. (1998) (Pol.) Przemiany pestycydów w organizmach żywych i środowisku. AGRAENVIRO LAB. Poznań.

Shuman E.K. (2010) Global climate change and infectious diseases. N Engl J Med, 362; 12, pp. 1061-1063.

Soderlund D.M., Bloomquist J.R. (1989) Neurotoxic actions of pyrethroid insecticides. Annu Rev Entiomol, 34, pp.77-96.

Soderlund D.M. et al. (2002) Mechanisms of pyrethroid neurotoxicity: implications for cumulative risk assessment. Toxicology, 171, pp. 3-59.

Stein E.A., Washburn M., Walczak C., Bloom A.S. (1987) Effects of pyrethroid insecticides on operant responding maintained by food. Neurotoxicol Teratol 9, pp. 27-31.

Verschoyle R.D., Aldridgwe W.N. (1980) Structure-activity relationships of some pyrethroids in rats. Arch Toxicol 45, pp. 325-329.

Verschoyle R.D, Barnes J.M. (1972) Toxicity of natural and synthetic pyrethrins to rats . Pestic Biochem Physiol, 2, pp. 308-311.

Watt B. (1998) FMC 548000 technical: acute neurotoxicity screen in rats. FMC Corporation Study No. A97-4642. 


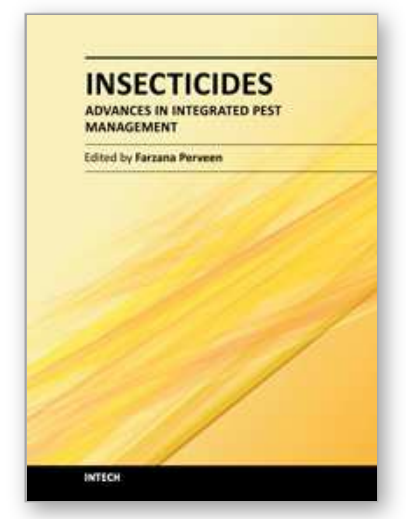

\author{
Insecticides - Advances in Integrated Pest Management \\ Edited by Dr. Farzana Perveen
}

ISBN 978-953-307-780-2

Hard cover, 708 pages

Publisher InTech

Published online 05, January, 2012

Published in print edition January, 2012

This book contains 30 Chapters divided into 5 Sections. Section A covers integrated pest management, alternative insect control strategies, ecological impact of insecticides as well as pesticides and drugs of forensic interest. Section B is dedicated to chemical control and health risks, applications for insecticides, metabolism of pesticides by human cytochrome p450, etc. Section $\mathrm{C}$ provides biochemical analyses of action of chlorfluazuron, pest control effects on seed yield, chemical ecology, quality control, development of ideal insecticide, insecticide resistance, etc. Section $D$ reviews current analytical methods, electroanalysis of insecticides, insecticide activity and secondary metabolites. Section E provides data contributing to better understanding of biological control through Bacillus sphaericus and B. thuringiensis, entomopathogenic nematodes insecticides, vector-borne disease, etc. The subject matter in this book should attract the reader's concern to support rational decisions regarding the use of pesticides.

\title{
How to reference
}

In order to correctly reference this scholarly work, feel free to copy and paste the following:

Barbara Nieradko-Iwanicka (2012). The Influence of Synthetic Pyrethroids on Memory Processes, Movement Activity and Co-Ordination in Mice, Insecticides - Advances in Integrated Pest Management, Dr. Farzana Perveen (Ed.), ISBN: 978-953-307-780-2, InTech, Available from:

http://www.intechopen.com/books/insecticides-advances-in-integrated-pest-management/the-influence-ofsynthetic-pyrethroids-on-memory-processes-movement-activity-and-co-ordination-in-mi

\section{INTECH}

open science | open minds

\section{InTech Europe}

University Campus STeP Ri

Slavka Krautzeka 83/A

51000 Rijeka, Croatia

Phone: +385 (51) 770447

Fax: +385 (51) 686166

www.intechopen.com

\section{InTech China}

Unit 405, Office Block, Hotel Equatorial Shanghai

No.65, Yan An Road (West), Shanghai, 200040, China

中国上海市延安西路 65 号上海国际贵都大饭店办公楼 405 单元

Phone: +86-21-62489820

Fax: $+86-21-62489821$ 
(C) 2012 The Author(s). Licensee IntechOpen. This is an open access article distributed under the terms of the Creative Commons Attribution 3.0 License, which permits unrestricted use, distribution, and reproduction in any medium, provided the original work is properly cited. 